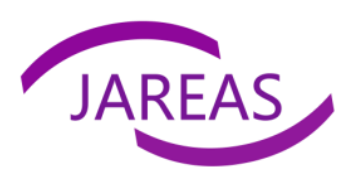

Journal of Advanced Research in Economics and Administrative Sciences

Website: https://bcsdjournals.com/index.php/jareas

ISSN 2708-9320 (Print) and 2709-0965 (Online)

Vol.2, Issue 3, 2021

DOI: https://doi.org/10.47631/jareas.v2i2.228

\title{
Effect of Trading Volume, Market Capitalization, Firm Size in explaining Return on Vultures
}

\section{Dedi Hariyanto}

Faculty of Economics and Business, University of Muhammadiyah Pontianak, Indonesia Email: dedi.hariyanto@unmuhpnk.ac.id

\begin{tabular}{|c|c|}
\hline Article Info & Abstract \\
\hline $\begin{array}{l}\text { Article history: } \\
\text { Received:12 February } 2021 \\
\text { Revised: } 16 \text { April } 2021\end{array}$ & $\begin{array}{l}\text { Purpose: The study aims to examine the effect of trading volume, market } \\
\text { capitalization, and firm size in explaining return on vultures in selected } \\
\text { companies in Indonesia. }\end{array}$ \\
\hline Accepted: 17 April 2021 & $\begin{array}{l}\text { Methodology/Approach/Design: The population is } 131 \text { JII forming companies } \\
\text { in IDX between December } 2009 \text { - May } 2010 \text { to December } 2019 \text { - May } 2020 .\end{array}$ \\
\hline Keywords: & $\begin{array}{l}\text { All data is transformed into standard form because the model used is path } \\
\text { analysis. The corresponding regression of equation } 1 \text { is the Random Effect }\end{array}$ \\
\hline Return, & model and the corresponding Regression equation 2 is the Fixed Effect model. \\
\hline $\begin{array}{l}\text { Herding, } \\
\text { Firm Size, }\end{array}$ & $\begin{array}{l}\text { This study uses panel data analysis; the Chow test and Hausman test are also } \\
\text { used. Data is processed using statistics EViews software. }\end{array}$ \\
\hline Market Capitalization & $\begin{array}{l}\text { Results: The results of the equalization test } 1 \text {, trading volume has a significant } \\
\text { negative effect on the return of shares. The results also show that the market }\end{array}$ \\
\hline $\begin{array}{l}\text { JEL: G32, H21, C33, O54, } \\
\text { G30. }\end{array}$ & $\begin{array}{l}\text { capitalization has a significant negative effect on the return of shares, and } \\
\text { consequently the size of the company has a significant negative effect on the } \\
\text { return of shares. Hasil testing for equalization } 2 \text {, trading volume has a }\end{array}$ \\
\hline Paper Type : & significant effect on vultures, while market capitalization has no significant \\
\hline Research Article & $\begin{array}{l}\text { effect on vultures. The size of the company has a significant effect on vultures, } \\
\text { and the return of the company has a significant effect on vultures. }\end{array}$ \\
\hline Corresponding Author: & $\begin{array}{l}\text { Practical Implications: This research is limited to the variety of indices and } \\
\text { varieties of securities that become populations and samples. Future research }\end{array}$ \\
\hline Dedi Hariyanto & $\begin{array}{l}\text { can be developed by focusing on indices and securities as well as the } \\
\text { development of other variables in the behavioral finance section in addition to }\end{array}$ \\
\hline Email: & $\begin{array}{l}\text { Originality/Value: This study differs greatly from previous studies in } \\
\text { emerging markets in contributing to literature from a new direction in } \\
\text { exploring investor returns and herding. }\end{array}$ \\
\hline
\end{tabular}

\section{Introduction}

Follow-up behaviour in capital markets around the world has been widely reviewed and almost all of them are found to be follow-up behaviour. This participating behaviour in finance is called vultures. Herding reflects similarities in making investment decisions (Clements et al., 2017). Until now herding in the capital market is still under review and growing from what was done by previous studies. Related to that, the study of herding in the capital market is still a contentious issue. Vultures occur in all capital market players both individuals, institutional, domestic investors, foreign investors, male investors, women, and fund managers. Domestic individual investors also do herding (Tan et al., 2008; Christoffersen \& Stæhr, 2019). Herding conducted by individual investors is based on the limitations of the information obtained. Individual investors rely more on public information for their trades as they are influenced by market sentiment and eye-catching events (Wei et al., 2016). 
In developing countries vultures are very common. Emerging markets demonstrate evidence of significant vultures ( Chang \& Joseph 2006; Khorana \& Ajay, 2000). Developing countries in the southeast have inefficient capital markets that also result in the occurrence of asymmetric information. Herding behaviour occurs due to information asymmetry among investors (Javaira \& Hassan, 2015). Many factors cause vultures in the capital market and the dominant factor is the occurrence of crises in the country or globally that cause the market to decline steadily. The herding effect became stronger during the global financial crisis (Economou et al., 2011). The health crisis caused by COVID-19, which has been designated by the WHO as a global pandemic on March 11, 2020, caused global markets to decline steadily. Economic decline due to the pandemic is a very relevant topic in relation to vultures in the capital market for research. The economic impact of the global pandemic has been influential in shaping the public health response to infectious diseases (Peckham, 2013).

This study differs greatly from previous studies in emerging markets in contributing to literature from a new direction in exploring whether trading volume, market capitalization, and company size is important in determining the effect of returns. The study also examines whether trading volume, market capitalization, company size and return are important in determining the influence of investor vultures.

\section{Literature Review}

\section{Effect of Trading Volume on Return Shares}

In making decisions in the capital market many things can help to make the right decision. Capital market participants have their strategy in predicting stocks that have future prospects. One of the most commonly used is trading volume. Trading volume is the information that signals the future movement of the stock price from the current events of either the purchase or the seller. The trading Volume of shares is an instrument used by investors to see the reaction of stocks in the market from financial statement information that causes the movement of stock trading activities.

Research on volume intraday trading and volatility of DJIA stock returns as noted by Darrat et al. (2002) shows positive and significant correlation results at the same time between gan trading volume and return volatility. In another study entitled Trading volume and crossautocorrelations in returns, the results of trading volumes are a significant determinant of crossautocorrelation lead-lag in stock returns (Chordia and Than, 2000). Based on this, the first hypothesis is formulated as follows:

\section{H1. Trading Volume has a significant influence on stock returns.}

\section{Effect of Market Capitalization on Stock Return}

The market capitalization in the capital market is short with the Market Cap which is the stock value of an issuer in the capital market. The value of this market capitalization is based on the

Copyright (C) 2021, Journal of Advanced Research in Economics and Administrative Sciences (JAREAS), Under a 
ups and downs of the share price in the market. Based on that, investors considered the market capitalization of a stock as very important to observe and make a decision. Research on the Influence of Current Ratio, Debt to Equity Ratio, Return on Assets, Dividend Yield, and Market Capitalization on Stock Return (Evidence of Manufacturing Company Listed on Indonesia Stock Exchange) showed a significant impact on stock market return (Maritoa \& Sjarif, 2020). As a result, the influence of market capitalization on the stock market was negative and insignificant.

\section{H.2. Market capitalization has a significant influence on returns}

\section{Effect of Firm Size on Return Shares}

The Company in carrying out its activities always leads to the growth of its assets. Asset growth is one indicator of management success. In review of the size or smallness of a company, not necessarily a large one generates maximum returns for investors. The size of the company is almost insignificant using monthly returns, but it is no longer significant in explaining the average return on shares using quarterly returns (Dongcheol, 1997). During the economic cycle, investment in 'style' factors such as company size also significantly affects the time series of risk and portfolio returns (Quiros and Timmermann, 2020).

\section{H.3. Firm size has a significant influence on stock returns}

\section{Effect of Trading Volume on Vultures}

Volume trading is a key element in predicting the movement of stock prices in the market because it is seen as an important part of the information that signals future price movements. The ups and downs of the volume fangs are determined by various factors both from within the company and from outside. Thus the trading volume is related to Signalling Theory (Stephen A Ross, 1977), based on the assumption that the information received by each party is not the same. The company's executives who have better information about the company will be encouraged to pass on the information to potential investors to increase the company's share price. Signal theory indicates the existence of information asymmetry between the management of the company and interested parties with information.

Investigation of the relationship between herding and liquidity in the Vietnamese stock market indicated that there is herd propensity (Vo \& Phan, 2019). The volume trading indicator compares the trading volume on a given day with the average movement of the previous 30 days to determine the liquidity level. Its findings detect significant anecdotal evidence of vultures for intermediate market liquidity conditions for the entire sample and most sub-periods. For high and low liquidity conditions, the results differ somewhat depending on the specific period.

After reviewing related theories and previous research, the researcher concluded that volume trading had a significant influence on herding. To that end, the fourth hypothesis in this study states:

H.4. Trading volume has a significant influence on vultures.

Copyright (C) 2021, Journal of Advanced Research in Economics and Administrative Sciences (JAREAS), Under a Creative Commons Attribution 4.0 International License 


\section{Effect of Market Capitalization on Vultures}

Market capitalization indicates the value of stocks in circulation in the market, the higher the value reflects the more expensive the company is appreciated by investors. The market cap value is not the same as the overall value of the company's assets. The value may be smaller or greater than the total value of the company's assets. Market capitalization is very meaningful for investors in the basic consideration of the characteristics, risks, and level of investor interest in the company shares. Hence, capitalization is information for investors; it can be attributed to Signalling Theory (Stephen A Ross, 1977). Market capitalization is public information so investors can observe in advance to make decisions the next day based on those observations.

Bowe \& Domuta (2004) researched the Indonesian stock market and concluded that there are herding domestic investors and foreign investors. In addition, it is pointed out that market capitalization shows a significant positive relationship. Kremer \& Nautz (2013) studied the causes and consequences of vultures by institutional investors. The Size i.t-1 indicator measures market capitalization and the findings of the study were positively related to herding behaviour. Hsieh (2013 examined the herding behaviour of institutional and individual investors on the Taiwan stock market with market capitalization indicators measured by the logarithm of the closing market capitalization of the stock. His findings indicate that Institutional investors prefer companies with smaller capitalization and lower turnover, and they follow a positive feedback strategy.

Herding research in eight African border stock markets between January 2002 and July 2015, showed limited evidence of vultures in border markets (Guney et al., 2017). The market capitalization indicator is a small part of the stock market capitalization on day $t$ divided by the number of market capitalizations of all stocks traded on day t. The magnitude of the vulture grows larger when the vulture is estimated to be based on a comparable weight test (compared to value), which indicates that the smaller capitalization of the stock increases in size; this is not surprising, given the uncertainty of greater information around smaller stocks, causing investors more vultures when trading them. After reviewing related theories and previous studies, the researcher concluded that market capitalization had a significant influence on vultures. To that end, the fifth hypothesis in this study states:

\section{H5. Market capitalization has a significant influence on vultures.}

\section{The Effect of Firm Size on Vultures}

Firm size describes the size of the company as reflected in the financial statements. Information from finance departments becomes a reference for investors in making investment decisions. From the financial statements, there is a signal for investors in assessing the company because it presents past information to assess the company's future business prospects. In this case, theoretically firm size can be linked to the theory of signaling (Spence, 1973), which states a company should give signals to users of financial statements.

Copyright (C) 2021, Journal of Advanced Research in Economics and Administrative Sciences (JAREAS), Under a 
Research testing the tendency of individual, institutional and foreign investors to vultures in Japan found that annual ownership changes are used as proxy vulture investors (Iihara, 2001). The firm size indicator is the annual cross-sectional average of the ratio of the number of shares held by each of the three types of investors to the number of shares outstanding. Its findings Herding behaviour of foreign investors appears to be similar to the vulture behaviour of U.S. institutional investors and the initial level of ownership, the selected time period, and the size of the company. Observation of herding investors during the financial crisis of the Jakarta Stock Exchange showed an association between vultures and company size (Bowe \& Domuta, 2004). Firm size indicators by way of stocks are included in five portfolios with allocations according to size (S1 the smallest and S5 the largest). Each portfolio generally contains between 30 and 50 stocks. Hence, previous studies indicate that domestic vultures are associated with the size of the company, but there is no evidence of foreign vultures conditioned to size.

Demirer \& Zhang (2018) discusses whether the characteristics of companies are important in determining the influence of investor vultures on asset returns. Firm size indicators at the end of each month, stocks in each industry are sorted to top (30\%), medium (40\%), and portfolio size down $(30 \%)$ (equal-weighted) based on 1-month. Market capitalization is divided into outstanding common shares. In each size, the group sorted stocks into industries to calculate the return of industries of the same weight. Its findings suggest that small companies with high vulture rates significantly perform under small companies that experience low vultures suggest that the vulture effect on returns is a phenomenon of small companies in an industry. After reviewing related theories and previous research, the researcher concluded that firm size has a significant influence on herding. To that end, the sixth hypothesis in this study states:

\section{H6. Firm size has a significant influence on vultures.}

\section{Effect of Stock Return on Vultures}

Herding is generally influenced by psychological factors that lead investors to take less logical actions in making investment decisions because it is influenced by various conditions. The conditions in question are when the market is up and down when there is abnormal volatility, when abnormal volume occurs, and when there is a crisis. The main purpose of herding behavior conducted by investors is to maximize returns by minimizing the search for information as the basis of investment decisions. Using the Cross-Sectional Absolute Deviation (CSAD) method, the researchers then used the return dispersion value (CSAD) as a dependent variable and the value of the absolute and squared market return $(\cdot \mathrm{Rmt} \cdot$ dan $\mathrm{R} 2 \mathrm{mt})$ as the independent variable (Chang, Cheng, and Khorana ,2000) as the inventors of the method of detection of vultures assume that, if there is an indication of herding behavior then the relationship between independent variables namely, squared market return $(\mathrm{R} 2 \mathrm{mt})$ and dependent variables i.e. return dispersion values (CSAD) is non-linear and significant negative, which can be seen from the negative and significant coefficient $\gamma 2(\gamma 2<0)$.

\section{H7. Market returns have a significant influence on herding}

Copyright (C) 2021, Journal of Advanced Research in Economics and Administrative Sciences (JAREAS), Under a Creative Commons Attribution 4.0 International License 


\section{Methodology and Procedures}

\section{Data}

Companies' financial report data are collected for each JII shaper's shares in IDX at daily and monthly frequencies obtained from The Indonesia Capital Market Institute (TICMI) and yahoo finance from December 2009 - May 2010 to December 2019 - May 2020. JII Index is an index that measures the price performance of 30 Shariah stocks that have good financial performance and high transaction liquidity. JII Index in 2 periods with JII review process conducted by IDX every May and November. Daily returns are used in the estimation of herding coefficients as described in the next section. All subsequent calculations to hold the return period are done using monthly returns.

\section{Methodology}

Data is processed using statistics eviews software. This study uses panel data analysis where the panel data is a combination of time series data and cross-section data. Data panel analysis techniques in this study can be done by common effect, fixed effect, and random-effect methods, while to determine which method is more appropriate to this research, the Chow test and Hausman test are used.

\section{Populations and Samples}

The population is $131 \mathrm{JII}$ forming companies in IDX between December 2009 - May 2010 to December 2019 - May 2020. Non-probability random sampling is used in selecting samples, while the criteria set to choose samples are: companies that entered as JII shapers between December 2009 - May 2010 to December 2019 - May 2020; companies that issue financial reports between 2010 and 2019. The sample is a JII forming company registered with IDX between December 2009 - May 2010 to December 2019 - May 2020 with an ongoing annual financial report. The total sample is 62 companies $\times 10$ years 620 observations. All data is transformed into standard form because the model used is Path Analysis.

\section{Results and Discussion}

\section{Regression Model Testing}

Model testing in regression data panel for both equations: Return of stock $=\mathrm{f}$ (trading volume, market capitalization, and company size); Herding in this case CSAD $=\mathrm{f}$ (trading volume, market capitalization, size of pe Perusahaan and return of shares) is done with three approach methods namely common effect models, fixed-effect models, and random effect models. The test result for the equation 1 Return stock $=\mathrm{f}$ (trading volume, market capitalization, and company size) using Common Effect Models obtained that the coefficient value in X1 (trading volume $)=-0.010221, \mathrm{X} 2$ (market capitalization $)=0.020621, \mathrm{X} 3$ (company size $)=-0.037749$ with R-squared of 0.011108. Using Fixed Effect Models does not pay attention to individual dimensions or time. It is assumed that the behaviour of data between regions is the same over

Copyright (C) 2021, Journal of Advanced Research in Economics and Administrative Sciences (JAREAS), Under a 
various periods. The regression results obtained that from the probability of each individual indicate that the three variables, $\mathrm{X} 1, \mathrm{X} 2$, and $\mathrm{X} 3$ are significant. $R$-squared represents 0.983228 . As for the F-statistical probability value of 502.4809 which gives the sense that the model is insignificant. The results of random effect models regression show that the probability of the three variables, namely $\mathrm{X} 1, \mathrm{X} 2$, and $\mathrm{X} 3$ is significant. $R$-squared shows0.080554 and F-statistic show the number 0.000000 which means the data is very significant.

The test result for equation 2, Herding $(\mathrm{CSAD})=\mathrm{f}$ (trading volume, market capitalization, company size and stock return) using common Effect Models obtained coefficient value at X1 $($ trading volume $)=0.010632, \mathrm{X} 2$ (market capitalization) $=-0.026549, \mathrm{X} 3$ (company size) $=$ 0.023395 , X4 (return of shares) $=1.092973$ with $R$-squared of 0.180170. Using Fixed Effect Models of each probability shows that three variables, X1 (trading volume), X3 (company size) and X4 (return of shares) are significant, X2 (market cap) is insignificant. $R$-squared represents 0.983228. As for the F-statistical probability value of 502.4809 which gives the sense that the model is insignificant. The results of the regression of Random Effect Models, show that the probability of three variables, namely $\mathrm{X} 1, \mathrm{X} 2$, and $\mathrm{X} 3$ is insignificant and $\mathrm{X} 4$ is significant. $R$ squared shows 0.126005 and F-statistic shows the number 0.000000 which means the data is very significant.

\section{Model Conformity Test}

\section{Lagrange Multiplier Test}

The result of using the Lagrange multiplier equation 1 indicates Breusch-Pagan probability value of 0.0000 . If breusch-pagan probability is smaller than alpha $(0.0000<0.05)$, then $\mathrm{H}_{0}$ is rejected and $\mathrm{H}_{1}$ is accepted, so the exact model on the result of using lagrange multiplier above is random effects. The result of using lagrange multiplier equation 2 indicates a breusch-pagan probability value of 0.0000 . The hypothesis is formulated as: if the breusch-pagan probability is smaller than alpha $(0.0000<0.05)$, then $\mathrm{H}_{0}$ is rejected and $\mathrm{H}_{1}$ is accepted, so the exact model in the Lagrange multiplier test result above is random effects.

\section{Redundant Fixed Effects}

The result of redundant fixed effects equation 1 has a probabiity value of $F$ of 0.0000 smaller than alpha 0.005 , so $\mathrm{H}_{0}$ is rejected and $\mathrm{H}_{1}$ is accepted, the corresponding model of the result is fixed effects. The redundant fixed effects result of equation 2 has a probabiity value of $\mathrm{F}$ of 0.0000 smaller than alpha 0.005 , so $\mathrm{H}_{0}$ is rejected and $\mathrm{H}_{1}$ is accepted, the corresponding model of the result is fixed effects.

\section{Hausman Test}

Hausman equation 1 test result obtained significance value 0.8242 (significance $>0.05$ ), then $\mathrm{H} 0$ rejected and $\mathrm{H} 1$ accepted, so it can be interpreted that random effects model is better than fixedeffects model. Hausman equation test result 2, significance value 0.0000 (significance > 0.05),

Copyright (C) 2021, Journal of Advanced Research in Economics and Administrative Sciences (JAREAS), Under a 
then $\mathrm{H} 0$ accepted and $\mathrm{H} 1$ rejected, so it can be interpreted that fixed effects model is better than random-effects model.

\section{Multiple Linear Regression Analysis}

After being selected the random effect model for the regression of equation 1and the fixed effects model for the regression of equation 2 as the best model used and has ensured that the regression model developed to test the hypothesis of this study has no problem with classical assumptions. Regression analysis in this study was conducted to determine whether the relationship between a dependent variable and an independent variable in the regression model. In this study for the equation of 1 dependent variable namely stock return (RS) and independent variable consisting of trading volume (TV), market capitalization (KP), company size (UP). The equation of 2 dependent variables is herding (CSAD) and independent variables consisting of trading volume (TV), market capitalization (KP), company size (UP) and stock return (RS). The results of the random regression effect for the regression of equation 1 are shown in the table as follows:

Table 1: RandomEffect Regression Results

Equation 1

\begin{tabular}{ccccc}
\hline \hline Variable & Coefficient & Std. Error & t-Statistic & Prob. \\
\hline \hline VOLUME & -0.005731 & 0.002543 & -2.253369 & 0.0247 \\
KAPITALISASI & -0.008631 & 0.003241 & -2.663190 & 0.0080 \\
SIZE & -0.022337 & 0.004007 & -5.574852 & 0.0000 \\
C & -0.008155 & 0.053889 & -0.151336 & 0.8798 \\
& $=$
\end{tabular}

Source: Eviews 9 Processed Products

Based on the test results shown by the table above, the double-digit linear regression equation used in this study is as follows:

$$
\mathrm{RS}=-\mathbf{0 . 0 0 8 1 5 5}-0.005731 . \mathrm{TV}-0.008631 . \mathrm{KP}-0.004007 . \mathrm{UP}+\varepsilon
$$

The fixed effect regression results for the regression of equation 2shown in the table as follows:

Copyright (C) 2021, Journal of Advanced Research in Economics and Administrative Sciences (JAREAS), Under a Creative Commons Attribution 4.0 International License 
Table 2: Fixed Effect Regression Results

Equation 2

\begin{tabular}{ccccc}
\hline \hline Variable & Coefficient & Std. Error & t-Statistic & Prob. \\
\hline \hline VOLUME & 0.069001 & 0.031187 & 2.212486 & 0.0275 \\
KAPITALISASI & 0.063531 & 0.039875 & 1.593277 & 0.1119 \\
SIZE & 0.190875 & 0.050692 & 3.765361 & 0.0002 \\
RETURN & 9.962288 & 0.594631 & 16.75374 & 0.0000 \\
C & 0.070884 & 0.028218 & 2.512021 & 0.0124 \\
\hline \hline
\end{tabular}

Source: Eviews 9 Processed Products

From the above results, the double linear regression equation used in this study is as follows:

$\mathrm{CSAD}=0.070884+0.069001 . \mathrm{TV}+0.063531 . \mathrm{KP}+0.190875 . \mathrm{UP}+$ 9.962288. RS $+\varepsilon$.

\section{Hypothesis Test}

\section{Statistical Test $\mathbf{t}$ Equation 1}

In this study, the resulting df (n-k) was $58(62-4)$, where $n$ of 62 was the number of observations and $\mathrm{k}=4$ was the number of dependent and independent variables. With a value of df 58 and a significance of 0.05 , the table t-value is 1.671553 . To find out if independent variables have a significant effect on dependent variables, using the test criteria if (thitung > ttabel) or ( $p$-value $<$ $0.05)$ then independent variables affect dependent variables. The test results equation 1 shown in table 1 above.

The Hypothesis "Trading Volume has a significant influence on the return of shares". Based on the test result of $t$ in table 4.20 above, trading volume has $t$ count of -2.253369 with significance level of 0.0247 . This indicates that the $t$ count is smaller than the table $t(-2.253369<1.671553)$ with a significance value $(0.0247<0.05)$. So, it can be concluded that, trading volume has a significant negative effect on the return of shares. The second hypothesis "Market capitalization has a significant influence on returns". Based on the results of the t test in table 4.20 above, the market capitalization has a calculated $t$ of -2.663190 with a significance rate of 0.0080 . This indicates that the $t$ count is smaller than the table $t(-2.663190<1.671553)$ with a significance value $(0.0080<0.05)$. So, it can be concluded that, market capitalization has a significant negative effect on the return of shares. The third hypothesis "Firm size has a significant influence on the return of shares". Based on the test result of t in table 4.20 above, firm size /size of the company has a $t$ count of -5.574852 with a significance level of 0.0000 . This indicates that the $t$ count is smaller than the table $t(-5.574852<1.671553)$ with a significance value $(0.0000<$ $0.05)$. So, it can be concluded that, the size of the company has a significant negative effect on the return of shares.

Copyright (C) 2021, Journal of Advanced Research in Economics and Administrative Sciences (JAREAS), Under a 
The test results t equation 2 shown in table 2 above. In this study, the resulting $\mathrm{df}(\mathrm{n}-\mathrm{k})$ was 57 (62-5), where $\mathrm{n}$ of 62 was the number of observations and $\mathrm{k}=5$ was the number of dependent and independent variables. With a value of df 57 and a significance of 0.05 , the table $\mathrm{t}$-value is 1.672029. The first hypothesis "Trading volume has a significant influence on vultures". Based on the test result of $\mathrm{t}$ in table 4.21 above, trading volume has $\mathrm{t}$ count of 2.212486 with a significance level of 0.0275 . This indicates that the calculated $t$ is greater than the table $t$ $(2.212486>1.672029)$ with a significance value $(0.0275<0.05)$. So, it can be concluded that trading volume has a significant effect on vultures.

The second hypothesis "Market capitalization has a significant influence on herding". Based on the results of the $t$ test in table 4.21 above, trading volume has a $t$ count of 1.593277 with a significance level of 0.1119 . This indicates that the t count is smaller than the table $\mathrm{t}(1.593277<$ $1.672029)$ with a significance value $(0.1119>0.05)$. So, it can be concluded that market capitalization has no significant effect on vultures. The third hypothesis "Firm size of the company has a significant influence on vultures". Based on the results of the t-test in table 4.21 above, the firm size of the company has a t count of 3.765361 with a significance level of 0.0002 . This indicates that the $t$ count is greater than the table $t(3.765361>1.672029)$ with a significance value $(0.0002<0.05)$. So, it can be concluded that, the size of the company has a significant effect on herding. The fourth hypothesis "corporate return has a significant influence on vultures". Based on the results of the t-test in table 4.21 above, the company's return has a t count of 16.75374 with a significance level of 0.0000 . This indicates that the calculated $t$ is greater than the table $t(16.75374>1.672029)$ with a significance value $(0.0000<0.05)$. So, it can be concluded that the company's return has a significant effect on herding.

P-test Coefficient of determination $\left(\mathrm{R}^{2}\right)$ equation 1 , adjusted result $\mathrm{R}^{2}$ of independent variables of 0.074635 or $7.46 \%$. This means that $7.46 \%$ of stock returns are affected and can be explained by the three independent variables in this study namely trading volume, market capitalization, and company size. While the other $92.54 \%$ is explained by other variables outside the regression model. Ptest Coefficient of determination $\left(\mathrm{R}^{2}\right)$ equation 2 , the result of adjusted $\mathrm{R}^{2}$ of independent variables of 0.118487 or $11.85 \%$. This means that $11.85 \%$ of stock returns are affected and can be explained by the three independent variables in this study namely trading volume, market capitalization, company size and stock return. While the other $88.15 \%$ is explained by other variables outside the regression model.

\section{Discussion}

\section{Equation 1}

Volume trading stocks of instruments used and describing the securities traded in the capital market. The share return caused the stock's trading volume at the same time to increase, and vice versa. From the results of the calculation and what has been explained above that trading volume has a significant negative effect on the return of shares. The increase in trading volume is an increase in the trading activity of investors on the exchange. The increasing volume of supply and demand of stock, the greater the influence on fluctuations in the price of shares on the stock

Copyright (C) 2021, Journal of Advanced Research in Economics and Administrative Sciences (JAREAS), Under a 
exchange, and the increasing volume of stock trading indicates the increasing demand for such shares by the public so that it will influence the rising price or return of shares

Large stock capitalization is a concern for investors to be included in the long-term portfolio. The greater the market capitalization of a stock, the longer the investor retains its shareholding; because investors assume that large companies will tend to be more stable from the financial side. From the results of the calculation and what has been explained above that the market capitalization has a significant negative effect on the return of shares. Companies with small sizes tend to have a higher return compared to companies with larger sizes, this phenomenon is commonly referred to as the size effect. The growth of a company is not only seen from the size of the company. The amount of an asset owned by the company if not managed properly then it will not be able to generate a large profit, the profit that is not maximal will make the share price decrease. From the results of the calculation and that has been explained above that the size of the company has a significant negative effect on the return of shares.

\section{Equation 2}

Stock trading volume is more reflective of investor activity due to new information through the summation of traded shares. Trading volume is used as an information asymmetry proxy. Trading volumes are positively correlated significantly causing investors to have the opportunity to behave accordingly. Investors who can develop their personal information will also follow other investors with different information in investment decision-making so that herding behaviour occurs in the market. From the results of the calculation and which has been explained above that trading volume has a significant effect on vultures.

The market capitalization of stocks traded in the capital market is divided into three groups based on their capitalization, namely: large capitalization, medium-capitalization, and smallcapitalization. In general, stocks that have a large-capitalization value become the target of investors for long-term investments because it describes the growth potential of a good company and has a low risk and has an impact on the behaviour of the investor to do herding. From the results of the calculation and that has been explained above that the market capitalization has no significant effect on the vultures.

The size of the company relates to the market demand for a stock, if the market reaction to stock is less then it will cause a drop in the share price so that it will decrease the capitalization value of the stock. Market capitalization reflects the company's current wealth and the occurrence of herding behavior in companies with a small market capitalization. Information-based herding theory explains that the imperfection of information on the market makes the investor unsure of the information he already has, so he will ignore the personal information and follow the actions of other investors. From the results of the calculation and that has been explained above the size of the company has a significant effect on vultures. Volatile market returns are one of the factors that provide opportunities for herding behaviour. With the high volatility of some stocks, investors should be able to make investment decisions quickly and precisely by first analyzing

Copyright (C) 2021, Journal of Advanced Research in Economics and Administrative Sciences (JAREAS), Under a 
any information that can be collected from the capital market. From rapid decision making as investors follow the market direction trail is by doing the herding. From the results of the calculation and that has been explained above the company's return has a significant effect on vultures.

\section{Conclusion and Suggestion}

All data is transformed into standard form because the model used is Path Analysis. Equation 1 is stock return $=\mathrm{f}$ (trading volume, market capitalization, company size), Equation 2 is vulture $(\mathrm{CSAD})=\mathrm{f}$ (trading volume, market capitalization, company size, stock return). The corresponding regression of equation 1 is the Random Effect model and the corresponding Regression equation 2 is the Fixed Effect model. Hypothesis testing in this study using two tools, namely: $\mathrm{t}$ statistical test, determination coefficient test $\left(\mathrm{R}^{2)}\right.$. The test results for the equivalent of 1 were obtained that the influence of each independent variable on dependent variables corresponds to the formulated hypotheses. The test results of the hypotheses are each: trading volume has a significant negative effect on the return of shares, market capitalization has a significant negative effect on the return of shares, and the size of the company has a significant negative effect on the return of shares. The test results for the equivalent of 1 were obtained that the influence of each independent variable on dependent variables in accordance with the hypotheses yang has been made except for independent variables of market capitalization. As for the explanation of testing hypotheses- hypotheses of each: trading volume has a significant effect on vultures, market capitalization has no significant effect on vultures, the size of the company has a significant effect on vultures, the size of the company has a significant effect on the vultures.

\section{Conflict of Interest}

The author of the article declares no conflict of interest.

\section{Funding}

This research study was not funded by any institution. The author conducted the study on his own expenses.

\section{References}

Bartram, S. M., \& Bodnar, G. M. (2012). Crossing the lines: The conditional relation between exchange rate exposure and stock returns in emerging and developed markets. Journal of International Money and Finance, 31(4), 766-792. doi:10.1016/j.jimonfin.2012.01.011

Bauer, R. G., Nadja; Otten, Roger. (2004). Empirical evidence on corporate governance in Europe: The effect on stock returns, firm value and performance. Journal of Asset Management, 5(2), 91-104

Bowe, M., \& Domuta, D. (2004). Investor herding during financial crisis: A clinical study of the Jakarta Stock Exchange. Pacific-Basin Finance Journal, 12(4), 387-418. doi:10.1016/j.pacfin.2003.09.003

Copyright (C) 2021, Journal of Advanced Research in Economics and Administrative Sciences (JAREAS), Under a Creative Commons Attribution 4.0 International License 
Chaffai, M. M., Imed (2018). Herding behavior in Islamic GCC stock market: a daily analysis. Journal of Emerging Markets, 10. doi:10.1108/IMEFM-08-2017-0220

Chang, E. C., \& Dong, S. (2006). Idiosyncratic volatility, fundamentals, and institutional herding: Evidence from the Japanese stock market. Pacific-Basin Finance Journal, 14(2), 135-154. doi:10.1016/j.pacfin.2005.09.001

Chang, E. C. C., Joseph. W ; Khorana, Ajay. (2000). An examination of herd behavior in equity markets: An international perspective. Journal of Banking \& Finance, 24, 1651-1679.

Chiang, T. C., \& Zheng, D. (2010). An empirical analysis of herd behavior in global stock markets. Journal of Banking \& Finance, 34(8), 1911-1921. doi:10.1016/j.jbankfin.2009.12.014

Choi, N., \& Skiba, H. (2015). Institutional herding in international markets. Journal of Banking \& Finance, 55, 246-259. doi:10.1016/j.jbankfin.2015.02.002

Christoffersen, J., \& Stæhr, S. (2019). Individual risk tolerance and herding behaviors in financial forecasts. European Financial Management, 25(5), 1348-1377. doi:10.1111/eufm.12231

Clements, A., Hurn, S., \& Shi, S. (2017). An empirical investigation of herding in the U.S. stock market. Economic Modelling, 67, 184-192. doi:10.1016/j.econmod.2016.12.015

Demirer, R., \& Zhang, H. (2018). Do firm characteristics matter in explaining the herding effect on returns? Review of Financial Economics, 37(2), 256-271. doi:10.1002/rfe.1036

Economou, F., Kostakis, A., \& Philippas, N. (2011). Cross-country effects in herding behaviour: Evidence from four south European markets. Journal of International Financial Markets, Institutions and Money, 21(3), 443-460. doi:10.1016/j.intfin.2011.01.005

Fuenzalida, D., Mongrut, S., Arteaga, J. R., \& Erausquin, A. (2013). Good corporate governance: Does it pay in Peru? Journal of Business Research, 66(10), 1759-1770. doi:10.1016/j.jbusres.2013.01.008

Galariotis, E. C., Rong, W., \& Spyrou, S. I. (2014). Herding on fundamental information: A comparative study. Journal of Banking \& Finance, 50, 589-598. doi:10.1016/j.jbankfin.2014.03.014

Gavriilidis, K., Kallinterakis, V., \& Tsalavoutas, I. (2015). Investor mood herding and the Ramadan effect. Journal of Economic Behavior \& Organization. doi:10.1016/j.jebo.2015.09.018

Gharaibeh , a. (2014). Capital Structure, Liquidity, And Stock Returns. European Scientific Journal, 10(25).

Guney, Y., Kallinterakis, V., \& Komba, G. (2017). Herding in frontier markets: Evidence from African stock exchanges. Journal of International Financial Markets, Institutions and Money, 47, 152-175. doi:10.1016/j.intfin.2016.11.001

Hoque, M. E., Yakob, N. A., \& Kruse, R. (2017). Revisiting stock market development and economic growth nexus: The moderating role of foreign capital inflows and exchange rates. Cogent Economics \& Finance, 5(1). doi:10.1080/23322039.2017.1329975

Hsieh, S.-F. (2013). Individual and institutional herding and the impact on stock returns: Evidence from Taiwan stock market. International Review of Financial Analysis, 29, 175-188. doi:10.1016/j.irfa.2013.01.003

Huang, T.-C., Wu, C.-C., \& Lin, B.-H. (2016). Institutional herding and risk-return relationship. Journal of Business Research, 69(6), 2073-2080. doi:10.1016/j.jbusres.2015.12.011

Ihrig, J., \& Prior, D. (2005). The effect of exchange rate fluctuations on multinationals' returns. Journal of Multinational Financial Management, 15(3), 273-286. doi:10.1016/j.mulfin.2004.09.004

Iihara, Y. K., Hideaki Kiyoshi; Tokunaga, Toshifumi. (2001). Investors' Herding on the TokyoStock Exchange International Riview Of Finance, 2(1/2), 71-98.

Copyright (C) 2021, Journal of Advanced Research in Economics and Administrative Sciences (JAREAS), Under a Creative Commons Attribution 4.0 International License 
Indārs, E. R., Savin, A., \& Lublóy, Á. (2019). Herding behaviour in an emerging market: Evidence from the Moscow Exchange. Emerging Markets Review, 38, 468-487. doi:10.1016/j.ememar.2018.12.002

Javaira, Z., \& Hassan, A. (2015). An examination of herding behavior in Pakistani stock market. International Journal of Emerging Markets, 10(3), 474-490. doi:10.1108/IJoEM-072011-0064

Jensen, M. C. M., William. H (1976). Theory of the Firm: Managerial Behavior, Agency Costs, and Ownership Structure. oumal of Financial Economics, 3, 305-360.

Kahneman, D. T., Amos. (1979). Prospect Theory: An Analysis Of Decision under risk. economitrica, 47(2), 263-292.

Kasman, S., Vardar, G., \& Tunç, G. (2011). The impact of interest rate and exchange rate volatility on banks' stock returns and volatility: Evidence from Turkey. Economic Modelling, 28(3), 1328-1334. doi:10.1016/j.econmod.2011.01.015

Keynes, J. M. (1936). The General Theory of Employment, Interest and Money. London: Macmilla, 403.

Kremer, S., \& Nautz, D. (2013). Causes and consequences of short-term institutional herding. Journal of Banking \& Finance, 37(5), 1676-1686. doi:10.1016/j.jbankfin.2012.12.006

Markowitz , H. (1952). The Utility Of Wealth.

Masulis, R. W. (1983). The Impact of Capital Structure Change on Firm Value: Some Estimates The Journal of Finance, XXXVIII(1).

Mobarek, A., Mollah, S., \& Keasey, K. (2014). A cross-country analysis of herd behavior in Europe. Journal of International Financial Markets, Institutions and Money, 32, 107127. doi:10.1016/j.intfin.2014.05.008

Peckham, R. (2013). Economies of contagion: financial crisis and pandemic. Economy and Society, 42(2), 226-248. doi:10.1080/03085147.2012.718626

Pierdzioch, C., Rülke, J.-C., \& Stadtmann, G. (2012). A Note on Forecasting Emerging Market Exchange Rates: Evidence of Anti-herding. Review of International Economics, 20(5), 974-984. doi:10.1111/roie.12007

$\mathrm{Pu}, \mathrm{G} .$, \& Jun, D. (2017). <Monetary policy, exchange rate fluctuation, and herding behavior in the.pdf $>$. Journal of Business Research. doi:10.1016/j.jbusres.2017.02.018

Q Jeon, J. M., Clay M. (2010). Herding by foreign investors and emerging market equity returns Evidence. International Review of Economics and Finance, 19, 698-710. doi:10.1016/j.iref.2010.03.001

Ross, S. A. (1977 ). The determination of financial structure: the incentive-signalling approach. The Bell Journal of Economics, 8, 23-40.

Salem, R. (2019). Examining the investment behavior of Arab women in the stock market. Journal of Behavioral and Experimental Finance, 22, 151-160. doi:10.1016/j.jbef.2019.03.001

Seo, S. W. C., Hae Jin. (2017). Capital structure and corporate reaction to negative stock return shocks. International Review of Economics \& Finance. doi:10.1016/j.iref.2017.02.005

Shefrin, H. S., Meir. (1985). The Disposition to Sell WinnersToo Early and Ride Losers Too Long: Theory and Evidence The Journal of Finance, XL(3), 287.

Simon, H. A. (1955). A Behavioral Model Of Rational Choice. Quartely Journal Of Economics.

Spence, M. (1973). Job market signaling. QUARTERLY JOURNAL OF ECONOMICS, 87, 355374.

Tabash, M. I., \& Dhankar, R. S. (2014). The flow of Islamic finance and economic growth: An empirical evidence of Middle East. Journal of Finance and Accounting, 2(1), 11-19.

Copyright (C) 2021, Journal of Advanced Research in Economics and Administrative Sciences (JAREAS), Under a Creative Commons Attribution 4.0 International License 
Tan, L., Chiang, T. C., Mason, J. R., \& Nelling, E. (2008). Herding behavior in Chinese stock markets: An examination of A and B shares. Pacific-Basin Finance Journal, 16(1-2), 6177. doi:10.1016/j.pacfin.2007.04.004

Vo, X. V., \& Phan, D. B. A. (2019). Herding and equity market liquidity in emerging market. Evidence from Vietnam. Journal of Behavioral and Experimental Finance, 24. doi:10.1016/j.jbef.2019.02.002

Wei, L., Ghon, R., \& Shuye, W. S. (2016). Differences in Herding Individual vs Institutional Investors. Pacific-Basin Finance Journal. doi:10.1016/j.pacfin.2016.11.005

Welch, I. (2004). Capital Structure and Stock Returns. ournal of Political Economy, 112(1), 1. 